\title{
Merezhkovsky's Neo-Christianity of the Third Testament: From Symbolist Historiosophy to Radical Politics
}

\author{
Vadim Polonsky
}

Citation: Polonsky, Vadim. 2021. Merezhkovsky's Neo-Christianity of the Third Testament: From Symbolist Historiosophy to Radical Politics. Religions 12: 456. https://doi.org/ $10.3390 /$ rel12070456

Academic Editor: Dennis Ioffe

Received: 6 May 2021

Accepted: 16 June 2021

Published: 22 June 2021

Publisher's Note: MDPI stays neutral with regard to jurisdictional claims in published maps and institutional affiliations.

Copyright: (C) 2021 by the author. Licensee MDPI, Basel, Switzerland. This article is an open access article distributed under the terms and conditions of the Creative Commons Attribution (CC BY) license (https:/ / creativecommons.org/licenses/by/ $4.0 /)$.
Gorky Institute of World Literature of the Russian Academy of Sciences, 121069 Moscow, Russia; v.polonski@imli.ru

\begin{abstract}
This article places Dmitry Merezhkovsky's Chiliastic concept of Three Testaments into a unified structure. The author analyzes the writer's integral system of Christological, anthropological, and historiosophicidiomyths and meta-symbols. He studies the religious, philosophical, and aesthetic genesis of the semantic transformation of traditional theological constructions and the doctrinal compilation of Russian fin de siècle culture dominant elements. It is shown how religious Modernist mythmaking alters political reality in Merezhkovsky's mind and draws him towards radical ideologies of the extreme left and right.
\end{abstract}

Keywords: Merezhkovsky; Third Testament; symbolism; chiliasm; New Religious Consciousness

\section{Introduction}

Dmitry Merezhkovsky lived from 1865 to 1941 and was one of the founders of Russian Symbolism. His late works were framed by an integral religious and philosophical concept. Gradually forming in the second part of the 1890s, it was completed in the beginning of the new century and would survive without any notable changes until his final days.

In Russia, this type of Weltanschauung was connected with the so-called "New Religious Consciousness", which was simultaneously a foreshadowing of a cultural and religious Renaissance at the turn of the century. It was a partly parallel phenomenon of the "Catholic renewal" ("le renouveaucatholique") in the West and was equally opposite to secular Positivism, 19th century Materialism, and to the strict dogmatic Church tradition.

According to Merezhkovsky, the base of this worldview is a universal, symbolic, and mythological construct. He perceives all world history as an opposition and antithesis of two primal sources, the "abyss of flesh" and the "abyss of spirit". The first is epitomized in Paganism, in the ancient cult of a heroic personality, which can be referred to as a "Man-God" (chelovekobozhestvo), who neglects the spirit. The second lies in historical Christianity, in asceticism, which dismisses the flesh. Both primal sources are imperfect. A real "spiritual revolution" is necessary, which is an amalgamation and synthesis of two abysses, two truths.

As Merezhkovsky points out, this synthesis can only be possible within a future new Church. Merezhkovsky himself and his wife, Zinaida Gippius, a loyal companion and spiritual collaborator through the years of their marriage, called this new church "Universal". Taken from the Apostle John (whose revelation about the Holy City of Jerusalem that will come down from heaven was especially significant for the God-seeking utopias of the Russian Symbolists). Alternatively referred to as "the Church of the Third Testament", whose concept emerged from the strong chiliastic tradition, from Montanus of Phrygia (II AD) to the Calabrian monk Joachim of Fiore (12th century).

This doctrine states the First Testament was the Old Testament of God the Father; the Second was the New Testament by God the Son, Jesus Christ; followed by the Third Testament, the Testament of the Holy Spirit, which is the covenant of Freedom that follows Law and Grace. That is how the sacred mystery of the Holy Trinity will be explained. The 
historical process will accordingly face its end and "a New Heaven and a New Earth" will come as promised in the Book of Revelation, as the thousand-year reign of Jesus Christ.

Merezhkovsky became a Prophet of the forthcoming Kingdom of the Third Testament. Since then, each and every facet of his literary and social activity was focused to that end. That is why it is close to impossible to have a grasp of either his works or the mere facts of his biography, without being fully aware of his doctrine.

The core of Merezhkovsky's position rests on the three stages of dialectics and accords with the Symbolist principles of peculiar interpretations of Baudelaire's correspondances (not to mention that mutual projections and "consistency" among the manifestations of the different semantic lines replace by themselves the hierarchy of values), which is: every phenomenon should be established as a conflict between thesis and antithesis, which is finalized in synthesis.

\section{On the Way to the New Church and "Religious Community"}

As a Symbolist Merezhkovsky had always remained an adherent of the idea of "lifecreation" (zhiznetvorchestvo). Referring to the permeation of noumenal and phenomenal, he rejected any borderline between eidoi and reality and was consistently striving to bring to life his literary and philosophical narratives. In his fiction, he was also trying to impose into historical characters (such as Byzantium Emperor Julian the Apostate, Leonardo da Vinci, Peter the Great and son, Grand Duke Alexei, Napoleon, and Dante) thoughts and actions that would be more suitable for their symbolic rather than historical role, i.e., the role which is assumed to be theirs in accordance with Merezhkovsky's own religious myth of the Third Testament.

In a conceptual Thesaurus created by Merezhkovsky, the main is the antithesis "contemplation vs. action": Dialectics calls for the transformation of the first into the second. Indeed, it was not surprising, and it was also absolutely logical, that when at the very end of the 19th Century the chiliastic doctrine of the three Testaments was formed in Merezhkovsky's mind, the necessity of the practical realisation of its results had emerged as well.

In her diary "On the Past" Zinaida Gippius writes:

In October 1899 Dmitry Sergeyevich Merezhkovsky came to me and said: “No. We need a new Church".

We talked a lot about that afterwards, and that was what we learned: the Church is necessary as the face of evangelical, Christian religion, the religion of Flesh and Blood.

The existing Church in its base cannot satisfy either us or the people who are close to us in time (Gippius 1999, p. 89).

It did not take long for the transition to action. By 1901 Merezhkovsky and Gippius created something which resembled the domestic church with chiliastic dogmas and their own rituals. They did it together with their mutual friend Dmitry Filosofov. He was essentially a member of their family. The literary couple connected to him on the basis of a "spiritual affinity" but there might have been traces of a sublimated Modernist Eros (Matich 2008, pp. 170-225).

They established their own liturgical order, the succession of prayers, made their own liturgical garments, obtained a communion chalice and held at home the very first service on Maundy Thursday in 1901 (Gippius 1999, pp. 95, 97-98; Gaidenko 2000).

In this regard Olga Matich has candidly noted that "the Triple Union of Merezhkovskys exemplified the idea of a neo-Christian Holy Trinity. The mediator was Gippius, playing the role of Sophia, Blessed Virgin and the Holy Spirit." (Matich 1999, p. 114).

Using the esoteric language of the "Trinity," the chiliastic doctrine of three testaments in its entirety was called "The Main [Doctrine]" (Glavnoye). It could be discussed directly only with those who were part of the narrow circle of initiates. As for the wider circles, they were provided with overall more subtle and careful messages, which did not reveal the radical nature of the "Third Testament" beliefs. Instead, it was presented as no more than an "upgrade" of the Church and Christianity. 
In order to expound their ideas, Merezhkovsky and Gippius launched the ReligiousPhilosophical Meetings in St Petersburg (1901-1903). These meetings marked the first Russian attempt since post-Petrine history in the 18th century of informal interactions and doctrinal discussions between the secular "God-seeking" intelligentsia and representatives of the official Russian Church. Furthermore, the Merezhkovskys were in fact those who began the whole new "genre" of church-secular intellectual and social dialogue. Continuing in the West through the trial of "catholic renewal" as happened for example, in the case of the famous "Decades of Pontigny" organized by Paul Desjardins in 1910 (Chaubet 2000).

The Russian Revolution of 1905 (the First Russian Revolution) drastically radicalized Merezhkovsky's Weltanschauung, and he started propounding the ideas of a "new religious community." In the beginning of 1906, the Merezhkovskys fled Russia and during the next two and a half years they preached their sermon from Paris. The anti-clerical atmosphere in the French capital generated by the controversial separation of Church and State, initiated by the 1905 law, contributed to the sharp politicization of religious and social issues. Their sermon, most vividly embodied in the collected French language edition by Merezhkovsky, Gippius, and Filosofov, Le Tsar et la Révolution (1907), primarily focused on "the religious justification for the Russian revolution and clearly expressed an anti-monarchy and anticlerical perspective" (Pavlova 1999, p. 7).

Completing the international questionnaire of the magazine Mercure de France in 1907, "On the Religious Issue," Merezhkovsky stressed that "the future religious revolution will resemble the one that happened when Christianity was born." [La future révolution religieuse sera pareille à celle qui s'accomplit lors de la naissance du christianisme] (Merezhkovsky 1907, p. 68).

It is difficult to disagree with E. Goncharova when she said that:

The Russian Revolution was seen by the Merezhkovskys as a chance to release their own religious intentions. The revolution should slide from the social and political surface into the religious depths. Meanwhile, the revolutionary struggle is regarded as one of those types of sacrificial fight for world transformation (Goncharova 2009, p. 10).

Interestingly enough, here the Symbolist writer expresses a, typical for mythological mentality, interchangeability of a subject and an object; those who sacrifice others have obtained the status of the main victim. It is not a coincidence that at the same time, during the years of the first Paris residence, the Merezhkovskys drew closer to Boris Savinkov. A notorious political activist, leader of the Fighting Organisation of the Socialist Revolutionary party, he was in charge of assassinations (or attempted assassinations) of a number of prominent high-ranking officials of the Russian Empire (Goncharova 2009, pp. 5-88). In Merezhkovsky's essays of that time, the way of revolutionary terror is considered as the Via Dolorosa to the Calvary of full self-sacrifice. For Merezhkovsky, the hidden holiness of notorious atheists, i.e., revolutionists and terrorists whose activities he compared with Jacob wrestling with God (Jacob forced his Celestial Adversary to bless him) in above questionnaire, is unconditional: "That is why, whilst it seems strange, modern atheists, warriors with Christ, are closer to Him than modern Christians; not seeing His Image, not knowing His Name, they clasp Him in the fight, sense Him, unite with Him." [Et voilà pourquoi, bien que ceci semble étrange, les athées contemporains, les lutteurs avec Christ, sontplus proches du Christ que les chrétiens actuels: sans voir Son visage, sans connaître Son nom, ils le serrent dans la lutte, le touchent et s'unissent à lui] (Merezhkovsky 1907, p. 71).

Until the revolutionary events of 1917, Merezhkovsky held faith to his ideas and made few changes. He actively nourished his liaisons with socialist revolutionists and other radically opposed politicians of the last years of the Empire. However, come the Bolshevik October Uprising and his first experience of Soviet power, he revised his political position. Nonetheless Merezhkovsky's religious and missionary activity was cemented even stronger to its core during the last two decades of his life following emigration in 1920. 


\section{Works Abroad: Chiliastic Symbolism and Post-Apocalyptic Historiosophy}

In the late, emigrant, period of his life, Merezhkovsky's concealed potential was revealed. As a result of that, the expansion of two genre constructions appeared-first, his meta-historical prose, which included his essays and philosophical pieces, such as The Mystery of the Three: Egypt and Babylon (1925), Western Mystery of Atlantis-Europe (1930), and also Jesus the Unknown (1932-1934), and second, his biographies (taken in a broad sense), such as Napoleon (1929), Dante (1939), Little Theresa (1941), and collections Faces of Saints: from Jesus to Nowadays (1936-1938) and The Reformers and Spanish Mystics (1940-1941).

Relying upon the New Testament code, Merezhkovsky distinctively separates the concepts of history, myth, and mystery, endowing them with a whole new thematic meaning. History is an empirical reality, which is doomed to fall into the apocalyptic abyss of universal destruction if humankind does not manage to ascend to grasp the mystery. The universal action, the eternal archetype of dynamic existence based on a construction of celestial redemption is framed according to the ideology of the three Testaments by Joachim of Fiore. Which predetermines the essence of everything happening in Time. The path from the fog of history to the ontological clarity of the revelation of the final truths in the mystery goes through its iconic sign, or symbol, which is a myth in human culture. The mystery is hidden under the cover of a myth. "The truth of a myth lies in a mystery" (Merezhkovsky 1999, p. 14). "Prophets know that the myth is not a lie, but prototype of a divine truth, implemented in a mystery" (ibid., p. 174).

In emigration, Merezhkovsky's dialectical chiliasm gained eschatological elements and became a source of a line of subordinate ideological implications (such as non-religious Christocentrism, Ecumenical church, bisexuality, femininity-maternity-spirit etc.), defining an informative side of practically in his late works.

Karl Löwith wrote:

It is well known how deeply Russian thinkers of the nineteenth century have been influenced by Hegel and Schelling. It is therefore not surprising to find many parallels among them, for instance, in Krasinski's Third Realm of the Holy Spirit and in Merezhkovsky's Third Testament Christianity (Löwith 1949, p. 210).

Of course, there were other sources out there for Merezhkovsky to adopt the ideas of Joachim of Fiore: Henrik Ibsen was undoubtedly one of them. Ibsen was the author of a chiliastic dilogy, Emperor and Galilean (1874), which Merezhkovsky was certainly familiar with while working on his novel on Julian the Apostate in the early 1890s (Fridlender 1995). Another is the eschatology of Vladimir Solovyov (Gaidenko 2001, pp. 327-55; Mozgovaya 1996) and all of Solovyov's "landscape" of Russian intellectual fin de siècle culture, starting from the scandalously famous Anna Schmidt who created her ludicrous opus, The Third Testament (Kozyrev 1996). This line—of a double succession—was quite evident for Merezhkovsky's contemporaries, and Andrei Bely confirmed it: Merezhkovsky "twisted Ibsen and Vladimir Solovyov into a confession: the Third Testament-The Testament of a Spirit" (Bely 1997, p. 31).

Yet unlike Junior Symbolists, Merezhkovsky did not truly adopt the main myth making ideas of Solovyov's Sophiology. His creations do not need that immanent necessity in Sophia as a mystical medium. On the contrary, Solovyov cannot fathom a metaphysical drama of world duality as well as his doctrine of "positive all-unity" without it. Solovyov was absolutely unfamiliar with verbal formalism, which was one of the characteristics of Merezhkovsky's thinking, making it very often so scholastic and lifeless. Merezhkovsky was one of a few fin de siècle thinkers who perceived Sophia with a certain distraction from its Gnostic/mystical roots. His version of Eternal Femininity is more rational and its origins can be found in the Goethe-Nietzschean image of Aphrodite-Venus from the trilogy Christ and Antichrist (1895-1905). It has to be understood allegorically, as a onedimensional incarnation of a synthesis of heaven and earth in the Church of the Second Coming. According to Merezhkovsky, this image splits into a series of doubling and flowing into each other derivatives, from chthonic "Mother Goddess" to the Virgin: 
Mighty Mother Goddess, which is the mother of not only our second generation of humankind, but the first, too-Crete-Aegean Britomartis, Hellenic Aphrodite the Divine, Urania, Babylonian Ishtar, Canaanite Astarte, Iranian Anahita—the eternal Mother Virgin, with the Child (Merezhkovsky 1996, p. 160).

Synthesising them all, Merezhkovsky created a symbol of the Holy Spirit.

Due to that peculiar eschatologically stressed view of history, Merezhkovsky found himself perceiving the modern era as the time of an inevitable finale. The apocalyptic destruction of "the aeon of this age," which will be followed by "The Final Judgment" and an installation of the "Kingdom of the Third Testament". A community of Saints, a redemption of heaven and earth by the creative power of the Heavenly Spirit. The numerological symbolism of the number three and Trinitarian dialectics form the basis of a historiosophical proto-myth of Merezhkovsky. Hence, they shape the content of practically all of his late prose. In his book The Mystery of the Three: Egypt and Babylon Merezhkovsky presents his concept of "Three-in-One":

The Orphics called the Kabirs by three names or one of three: Axier, Axiokersa, Axiokers: Zeus the Heavenly Father, Demeter the Mother Earth, and the Son of Heaven and Earth Dionysus. The same Three in the Eleusinian Mysteries, just in a different combination: Father Dionysus, Mother Demeter and Son Iacchus. (Merezhkovsky 1999, p. 20).

In Merezhkovsky's perception, the poem by Heraclitus is also an embodiment of "the Mystery of the Three". In his interpretation, the idea of God the Shepherd spread from Babylon to Israel through the trihypostatic deity, Tammuz-Adonis-Adonai, and then reached modern civilization in Christ's image. C. H. Bedford describes the essence of the Trinitarian system of Merezhkovsky as following:

God the Mother is the term, which provides the wholesomeness for Christianity, because God the Father could not give birth to a Son without an involvement of divine femininity. Merezhkovsky approved of the significance of the terrestrial Mother of Christ, but saw in Her a symbol only, which referred to the Divine Mother, who can complete the Trinity; the Trinity in God begins and ends with Mother the Spirit. (Bedford 1975, p. 161).

The researcher elaborates that the apocryphal New Testament according to the Jews determines the connection between Merezhkovsky's concepts of the Holy Spirit and the doctrine of eternal motherhood. There were words in there about "My Mother, the Holy Spirit," that belonged to Christ. There is no argument against it, especially taking into account the aforementioned source, which was quoted by the author regularly and in different contexts. This apocryphal prayer will undergo a symbolic re-enactment and will become one of the leitmotivs of his historiosophical writings. Merezhkovsky establishes the Trinitarian principle as the main law ruling the world and mankind, including the past, the present, and the future. Space, chemical reactions/organic life, and the universal evolution, where the antipodal processes of integration and differentiation are merged together, are the Triune.

For Merezhkovsky, mysteries, i.e., a sacred meta-narrative of Divine self-emptying, His kenosis, His sacrifice for the sake of salvation of His creation in order to its next reunion with the Creator, establish a proto-myth of history, which is the code to a Symbolist description of the inner mechanism of unfolding the path of the world in time. Incarnation, or the birth of Jesus Christ, which signifies the middle way of the Trinitarian historic and mysterial narrative, is the core of this proto-myth. As a Christian thinker, Merezhkovsky is more than a traditionalist here. This scheme, however, gets more non-standard when he deconstructs the actual historical chronotope with his sacred symbolism. The Mediterranean, which connects three parts of the world, is, according to Merezhkovsky, the heart of the Earth, and two lines drown from Memphis to Constantinople and from Babylon to Rome have created the cross, a proto-image of the Calvary Cross, upon which the path of world history is unleashing itself.

The cult history of a pre-Christian man is a shadow, a Platonic anamnesis, a recollection of the future mystery of Incarnation and Redemption. At the very beginning of the first 
part of the trilogy, Merezhkovsky reveals his views on the significance of pre-Christian history as a myth/proto-image in regard to the coming of the Savior of the world-and he does it with formulaic brilliance:

The whole matter of the world mystery-myth about the suffering God is an event, which has not happened once but always does, is happening again and again in the life of the whole world and mankind. "Now these things never happened, but always are." (Sallust. De diis et mundo, IV) ${ }^{1}$. "The world history is an aeon whose essence is eternal, and the beginning and the end, the reason and the purpose is Christ." (Schelling). Christ is concealed in Paganism: He opens up in Christianity. Christ is Revelation, Apocalypse of Paganism. Those who blind cannot see the Sun but can feel its warmth. The Pagan's Christ is the Son of the blind. World history is a geometrical space where the Body of Christ is built (Merezhkovsky 1999, p. 18).

A similar view of the mutual correlation between Paganism and Christianity is, in fact, a leitmotif of the primary religious and philosophical intuitions of the Russian Silver Age, which predefines a pathos of the whole Dionysian theme in the essays and academic works of Vyacheslav Ivanov, for example. This view was clearly shown by Merezhkovsky in his Julian the Apostate (1895). It is originated from the immense tradition of the early Christian apologetics, from Justin the Martyr to Clement of Alexandria (the treatise The Stromata), who apparently was the most frequently quoted by Merezhkovsky. Those ideas were adopted by the early Christian tradition due to the necessity to explain the visual similarity between the mysteries of the bloodless sacrifice of the Savior and the liturgical Eucharist, on one side, and the orgiastic ${ }^{2}$, on the other. Merezhkovsky, a master of quotation, constantly feels the need to refer to the authorities in order to validate his own place in the line of succession in "Christian gnosis":

Once learning from the Judaic prophets about the forthcoming arrival of the Lord, demons decided to invent a fable about Dionysus the god for distribution among Hellenes and other peoples, especially in places where, as they knew, everyone would believe their prophecies," thought Julian the Apostate, who lived in the 2nd century AD. $<\ldots$ $>$ "Demons" were preaching about that "Son of God," Dionysus the dismembered instead of Jesus the Crucified, further and earlier that Julian assumed, from the very early days of mankind until the Appearance of Christ, from Egypt and Babylon to Peru and Mexico. St. Clement of Alexandria gently argues, "Both Hellenistic and barbarian wisdom can see eternal truth in certain dismembering and crucifixion, but not in that which was described in Dionysian fables but in that which teaches the theology of eternal Logos (ibid., pp. 506-7).

Explaining the consequence of the writing order of his historiosophical trilogy, Merezhkovsky points out that "the Mystery of the East" (the Mystery of the Beginning) has led him to "the Mystery of the End" (the Mystery of the West), and since Jesus is "the Alpha and the Omega, the beginning and the end," the mystery of the East and the West is reduced to the mystery of Christ, whose solution will light up the meaning of history.

Merezhkovsky declares that historical Christianity put the true meaning of the mysteries into oblivion. That is why the main task of the new, eschatological, revelation is to show the history of Jesus the Unknown, to unveil the core of "the Testament from the Saviour," to bestow upon the world the gospel of the "mystery of the three".

The first part of The Mystery of the Three is an attempt made by Merezhkovsky, who was always thinking by antithesis, to find the origins of one of the basic dichotomies-belief and knowledge, mysticism, and rationality—in the religions of ancient Egypt and Babylon.

In Merezhkovsky's thinking, Egyptian cults bring up the semantics of a solar insight, harmonious cosmos, and Love. It is worth noticing, however, that those exact implications are quite unusual for the mainstream perception of Egypt in Russian literature, despite a variety of already existing "variants". ${ }^{3}$ Harmonious radiance could be hardly ranked as one of the main attributes of the "Russian Egypt." But Merezhkovsky himself does indeed understand how ambiguous all the eschatological categories could be in regard to the civilization of the Nile. He emphasizes that the religion of Egypt did not have the 
experience of being infiltrated by the metaphysics of evil and, therefore, did not have that dialectical inclination towards eschatology.

Babylon is in opposition to Egypt. Its religion is the religion of the night, and Gilgamesh in Merezhkovsky's portrayal looks like the Faustian character that has comprehended that knowledge cannot be accomplished either in happiness or in eternity. Although the Babylonian symbolic character discovered that the way to Salvation lies through suffering, he was unable to give the world the true faith. Therefore, the Old Testament Israel became the synthesis of the antithesis "Egypt vs. Babylon", whose spiritual experience included the truth of faith and reason, day and night, Love and Suffering. That is how the dialectical circle of meaning-generation was completed and the Triad of mystical revelation of the pre-Christian era was formed.

\section{Theological Accompaniment: The Theme of Eros and Sex}

The principle of triplicity is layered onto the concept of sex, which is sublimated and connected to the entire religious doctrine in a sense of the Modernist paneroticism of the fin de siècle era. C. H. Bedford and T. Pachmuss rightly pointed out that for Merezhkovsky (and Zinaida Gippius), the category of sex took on a special meaning when they were in exile. At that time Merezhkovsky's speculations around the metaphysics of Eros got closer to the phallic/neo-religious ideas of his frenemy, Vasily Rozanov (Bedford 1975, p. 104; Rosenthal 1975, p. 92). However, the phallic inclination of Merezhkovsky's "philosophising" can be traced back to the 1890s, when his conceptual apparatus obtained the idea of the "sacred flesh".

However, before that, the influence of Rozanov's physiology was preceded by the philosophy of Eros by Vladimir Solovyov. As with Sophiology, Solovyov's impact on Merezhkovsky — to be precise, with his famous article The Meaning of Love (1892-1894) was rather formal. Merezhkovsky adopted the basic strategy on "sex spiritualisation" without digging deeply into Solovyov's mysticism of a personality's determination via its dissolution in love to the other. In the beginning of the new age Merezhkovsky's sacred flesh found its place in the terminological vocabulary of the "God-seeking" intelligentsia and was used as a generic term in the discussions of nearly all the main topics at the St Petersburg's Religious and Philosophical meetings in 1901-1903. The very name of the writer was connected in the collective mind of his contemporaries, the Junior Symbolists, with a tendency to erotic expansion into religious spheres. Simply by virtue of the fact that each and every key notion in Merezhkovsky's system unfolds into its opposite according to the logic of the inner antithesis, the "holiness of sex" bears the "abyss of sex," and behind it, there is another one, the "abyss of Sodom".

In his letter to Alexander Blok on 1 July 1902, young Sergei Solovyov expresses himself quite vividly on the matter:

Dmitry Sergeyevich <Merezhkovsky $>$ is greatly talented, but he forgets why exactly dogs are not allowed in church and cats are. He doesn't mind to let in notorious Isis, bless her heart, totally forgetting about her objectionable behaviour, and also Fyodor Pavlovich Karamazov as an underside of Christ etc. In general, I am feeling some concern for future historians of Russian literature, who would mark its phases in chronological order as Romanticism, Naturalism, Phallism etc. (Literaturnoy enasledstvo 1980, p. 330).

In his emigrant period, while canonizing Rozanov's image and heritage within a framework of his own, chiliastic, concept, Merezhkovsky reconciles and takes into account a number of Rozanov's main ideas that he has rejected before. For example, Rozanov's doctrine of sex, interpreted through a religious and cosmological perspective, became a leitmotif of Merezhkovsky's historiosophy. The mystery of sex "dissected by Rozanov," transformed by Merezhkovsky into "The Mystery of the Two," which is preparing on a sacred level the coming of "The Mystery of the Three," the era of the Holy Spirit. Reflecting upon the category of sex, Merezhkovsky strips it off from Rozanov's inevitable mundane physiology and, according to the laws of his own, "anti-natal," perception, transfers it into 
an abstraction, which does not have any blood pumping or flesh trembling, but the game of interpretations of the various literary sources and ancient texts.

Like Rozanov, Merezhkovsky in the last years of his life proclaimed the "sanctity" of pre-Christian phallic cults. However, unlike Rozanov, who offered to Christianity "inoculation by flesh," which had never been the part of it in the first place, Merezhkovsky interpreted the whole issue according to the triadic principle with which he was so familiar. Initially Judeo-Christianity knew the whole "mystery of sex," but then, in the era of the historical progression of the Church, that knowledge was lost and absorbed by ascetic modus of spiritual practice. Finally, "in the Holy Realm on earth and Heaven" that integrity will be found again as a consequence of the Third Testament.

In the neo-Christian ideology of Merezhkovsky, sex connects to a mystical concept of Love in a way that semantically conjoins to all the Greek words that exhibit all the variants of the meaning of the word in Russian. These are traditionally distinguished by Biblical exegetical scholars and theologians, including the words such as Eros (romantic/sensual attraction), philia (soulful affection, fondness), and agape (creative, all-forgiving, sacrificial, at best-Divine Love). Essentially, Merezhkovsky's theory directly refers to the idea that sex in its metaphysical manifestation is immanent to the eternal state of God the Trinity. Persona establishes the Mystery of the One; sex portrays the Mystery of the Two; community embodies the Mystery of the Three (tresfaciunt collegium).

"Sex" is also the basis of epistemological constructions in The Mystery of the Three. The holiness of sex is a "transcendental mystery," where a man "discovers communion with the heavenly world": "sexual longing is longing for knowledge, curiosity towards the transcendental" (Merezhkovsky 1999, p. 108), "sex is only possible for a human being, blood-and-flesh 'touching other worlds,' proximity to the transcendental entities. There is birth in sexual love, but there is also death, because everything that was born once, dies; death and birth are two paths to one place, or one path to there and here" (ibid., p. 29). Sex was perceived by Merezhkovsky as an epiphany of the Trinity in a human body, a primal sensual experience of the introduction to the ontological, non-separable and non-merged, Unity of the Three in One.

All these statements became the basis for the characteristics of the whole Pagan period of history with its orgiastic physiology as the era of the "Testament of the Father." There is no need to quote numerous examples made by Merezhkovsky about pre-Christian manifestations of sanctity of sex, from the "divine" (temple) prostitution of priestesses of Ishtar to the Egyptian bestialia, in which he, like Rozanov before him, saw the real example of viewing animals as creatures who are closer to the "divinity" than a man who has lost the ability of "heavenly joy of the earth." However, most evidently, the holiness of sex in the pre-Christian era incarnates for Merezhkovsky (as well as for Rozanov) in the Old Testament circumcision:

Circumcision is courtship between man and God, direct and fleshly. A marital testament, a matrimonial union, a sexual intercourse between man and God. It is strange and it is dreadful. And how can we talk about this using our damned words, which are shamelessly wild and anatomically cadaverous? That is exactly when "the tongue truly is sticking to the larynx, and the paper under the ink is burning, smouldering, crumbling" (V. Rozanov). However, is eating the Divine Body, nourishing humans with the Flesh and Blood of God less terrible and strange? "How odd are these words! Who can hear this?" His disciples were horrified when they heard this for the first time (ibid., p. 106).

For the era of "the Testament of the Father," this terrifying sacrament became similar in terms of an insight of mysterial depths with the Eucharist in the era of "the Testament of the Son." Circumcision and the Eucharist reflect on each other as the mystical cores of the two consequential Testaments. The sacrament of the Bloodless Sacrifice, which marks the victory over the flesh of the "mundane world" infested by sin and death, has its own pre-image, i.e., the fiery point of an exalted affirmation of not only flesh, but sex.

It is clear that Merezhkovsky's doctrine, in all its unorthodoxy, does not accept Rozanov's idea from the 1900s and, especially, from the period of The Apocalypse of Our 
Time (1917-1918), that Christ is the repudiation of the Father and that the New Testament broke with the Old. Following this logic, Merezhkovsky proclaims that Lord the Savior, circumcised according to the Law, finalized and strengthened the union between man and God with the Blood of the sacrament. Therefore, in circumcision the entirety of the affirmation of sex is merged with a succession between the two Testaments. In support of the thesis of the primary acceptance of sex by Christ, Merezhkovsky constantly refers to a symbolic image where Christ is shown as the Bridegroom and the Church as the Bride. This exact aspect is stressed in his exegesis of the New Testament. The actual example of this is his interpretation of the evangelical episode about healing the bleeding woman (Mark 5: 25-28), who "came up behind Him, because she was ashamed of her illness, hid it from people as they hide from each other their eternal 'shameful wound,' i.e., sex" (Merezhkovsky 1996, p. 228). Merezhkovsky explains this episode as follows: Christ took upon Himself the "shameful wound" of sex, which means that He accepted the "Testament of the Father".

According to Merezhkovsky (and he is close to Rozanov of the 1900s-the first part of the 1910s in here), Paganism has always revealed the deep connections between sex and the Resurrection. Hence, he adds his own definition of "the mystery of love in the Resurrection." This idea has been illustrated not only with various examples from the Pagan cults (the resurrection of Osiris by Isis, Tammuz by Ishtar, and the like), but also with the special interpretation of the Resurrection of Christ. Merezhkovsky especially stresses that the first person to discover that Jesus's tomb was empty and to meet him after the Resurrection, was a woman, Mary Magdalene. He elaborates that Mary Magdalene's love was stronger than death and the Resurrection itself became the miracle out of this love. Here the epigone scheme of Solovyov's Sophiology was getting rather obvious "the mystery of revealing the Eternal Feminine in the Eternal Masculine became clear" (ibid., pp. 324-25).

Love can be perceived as "antinomical," including also the "fleshly" feature, which, as was typical for Merezhkovsky, was expressed rather secretively, as a notorious example of the "metaphysical ambiguity" of his conceptual framework. This ambiguity and blurriness of the term "love" in Merezhkovsky's writings (he knew Greek quite well, by the way) are facilitated by him on purpose: he deliberately does not distinguish agape and Eros (and the last one is not found in the texts of the New Testament). By Merezhkovsky, Eros is some kind of perceptive emanation of agape. In his article "The Beatitudes" he writes: "Agape, so incomprehensible and terrifying for us, in His love that we did not experience, heavenly and earthly, became simple, easy and joyous in our love, earthly only-Eros". (Merezhkovsky 1933, p. 208).

In connection with this statement, P. Gaidenko has noted that:

Rozanov as a fighter against Christ in a certain sense is more consistent and "with all his fearless, almost shameless and cynical curiosity" is more honest and direct than Merezhkovsky: he rejects Christianity as a religion of the "immaculate conception" naming it a religion of death, non-existence, for the sake of the Astarte cult of "holy sex," "sacred semen." Opposing the Old Testament to the New, Judaism to Christianity, Rozanov simultaneously combines the Old Testament religion with the phallic cult of Cybele, which in reality is absolutely alien to the Testament by Moses and not only by Christ (Gaidenko 2001, p. 371).

As for the concept of the three testaments by Merezhkovsky, one of the mysteries of their "last revelation" is the connection of Cybele as a Pagan omen of the "Eternal Mysteries" not only with Moses's faith, but also with the Gospel of Christ. This ambiguity leads to the idea of the "consecration" of the demonic nature of Paganism. However, on the logical level it also helps to avoid a typical Gnostic alternative that was present as a subtext in Rozanov's writings in the 1900s and was almost openly manifested in The Apocalypse of Our Time. If there is a gap between the "physiological" Old Testament and the "spiritual" New Testament, then Christ rejects the world with its "mystical" phallism and inclinations to "flesh". Therefore, either the Creator (Demiurge) of this world is absolutely not the Merciful God, or Jesus is the only begotten Son of a completely different Father ${ }^{4}$. 
Despite being equipped with all the classical texts from antiquity, the erotically modernized Christology of Merezhkovsky, also heavily saturated by mythopoeic vapors, has another source-the widely popular fin de siècle exercises on the "mysticism of sex." Merezhkovsky is trying to link the "images of ideas" of Nietzsche, Vladimir Solovyov, Vasily Rozanov, and Otto Weininger in order to unite these in the ideological monolith of theological historiosophy, based on an inevitable semantic correction (in fact, quite radical) of the ecclesiastical dogmas and theological speculations. The synergistic union of man and God through divine kenosis, "depletion," which has appeared in the Incarnation of "the Holy Spirit and the Virgin Mary," is nearly replaced by circumcision and the sacrament of redemption become mundane. The Lord does not resurrect with divine power, which therefore executes the eternal will of the Trinity, but rather with the help of "spiritualised" earthly love of a common woman. This ought to be noted that first and foremost, as due to the doubling of "Sophiological" thought.

Various and exhaustive reflections by Merezhkovsky on soteriological themes are summarized by B. G. Rosenthal as following: "Sex is absolutely necessary for salvation. $<\ldots>$ sex must reveal the secret of creation itself" (Rosenthal 1975, pp. 107, 109).

The study of androgyne $\mathrm{e}^{5}$ created in the manner of Plato's Symposium and the subsequent Gnostic tradition became a peculiar synthesis of the philosophemes "femininemasculine origins of God" and "sex in love." It is also true that Merezhkovsky's immediate background at the time of adopting the actual subject was redefined by contemporaneous sources-i.e., the concepts of bipolarity and bisexuality by Otto Weininger. Overall, androgyny is quite a logical derivative of the total antithetical image of the worldview and a man produced by a mythos-creator and historyosophist.

Merezhkovsky postulates the presence of metaphysical features of the opposite sex in every living creature. In his mind, the ethos of both sexes is kept in Platonic/vertical proportions "Every man harbours a secret woman. The ethereal charm of a man is femininity and of a woman is masculinity." (Merezhkovsky 1999, p. 112). He takes this category out of the frameworks of the universal principle of the created world. According to Merezhkovsky, being androgynous is a sign of a deity. He finds its manifestations not only in Pagan cults $^{6}$ but also in the God of Israel from the Old Testament. That the Biblical Hebrew word ELOHIM is used in the Pentateuch in the plural Merezhkovsky interprets in the aforementioned sense, as an expression of the masculine/feminine duality of the Divine nature ${ }^{7}$. The same concept is based in the interpretation of the act of creation of a man in the Image of God with His immanent androgyny:

"And God said, Let us make man in our image, after our likeness." The Three GodsTwo in One-create a man in Their Image-two in one. "So God created man in his own image, in the image of God created he him; male and female created he them." (Gen. 1: 26-28). At first-“him," Man-woman, then "them", a man and a woman: two sexes in one creation was the meaning of the Image of God in a man. It seems it is impossible to convey the dogma about divine androgyny clearer: an Androgyne makes an Androgyne (ibid., p. 460).

Hence, according to the eternal plan of the Creator towards His creation, Adam was a "divine creature," an androgyne, and androgyny is a necessary and inseparable attribute of a persona. Analyzing the mythological body of Pagan cults, schematically simplifying the process of mythogenesis and not discussing such an important part of archetypical duality as the Twin duality (mostly same-sex), Merezhkovsky is trying to stress that a primitive man was androgynous in almost all etiological systems of ancient times. He split into two opposite sexes as a result of the Fall into sin and breaking up with the Divine Communion.

Masculine/feminine was "revealed" not only in Pagan deities and Jehovah, but also certainly in the Incarnated Logos, Lord Jesus Christ. With his typical casualness in choices and interpretations of the sources, Merezhkovsky, when talking about this side of Christ's persona, without further ado rejects the canonical gospel texts due to their "asexuality" and goes for apocryphal texts instead. He finds evidence about the "divine beauty" of Christ. Its origins, according to Merezhkovsky, lie exactly in the fact that this beauty does 
not specifically belong either to a man or a woman, but to the combination of masculine and feminine in the most glorious harmony" (Merezhkovsky 1996, p. 231), following the principle of Heraclitus, "the opposite is the unified".

Father and Mother in Son is the simplest geometrical figure of Androgyny and the Trinity in divine Eros-Logos as if it has been seen by the eyes of Numen of Sex. Because in our earthly geometry of the three dimensions sex is split by space into feminine and masculine, and in the fourth dimension, which is eternity, sex was before its birth, and shall be, after death, reunited and rebuilt in the primary oneness (Merezhkovsky 1999, p. 377).

As we can see, the thesis about the masculine/feminine in Christ was necessary for Merezhkovsky in order to complete his study about resurrection as the return to a primal state of personal wholeness-androgyny-in a logical way. In order to confirm his own thoughts and reflections, the writer gives a quote-leitmotif from a visibly Gnostic apocryphal Gospel of Thomas ${ }^{8}$ where it has been said that the Heavenly Kingdom will become reality "when two shall be one $\langle\ldots\rangle$ masculine will be feminine, and there will be neither masculine nor feminine." The shadow of this "third," "wholesome," sex in modernity Merezhkovsky sees in hermaphroditism and homosexual love, in Rozanov's complex of People of the Moon light:

Men love men, women love women, because feminine shines through masculine for the first ones and, vice versa, masculine shines through feminine for the second; as if the gold dust of primary androgyny, a whole man, an Androgyne, who is bigger than a modern man, split-in-two, to a man and to a woman, sparkles in the dark ore of two separate sexes. All this, which is possibly larger, primary-wholesome, perfect, enchants the "people of the moonlight" in homosexual love (Merezhkovsky 2007, p. 199).

Needless to say, the intellectually pedantic, dry, entirely bourgeois, and righteous Merezhkovsky was never an apologist for "sodomite frolics." The mystery of "people of the moonlight" as well as other frighteningly "shocking depths," like temple prostitution or anthropophagy, became the subject of his sublime poetic aphorisms and meditations only because, according to his doctrine, they were chosen as mythological signs of the genuine Mysteries. In the world of Merezhkovsky's Proteus-like antitheses, they could become a cloudy window to eternity but also could serve as satanic perversions of authentic meanings. And even the words quoted above—about "homoeroticism" - have undergone intellectual sublimation. The writer zealously denies every physical expression of homoerotic love, which he describes as an opposition to spiritual androgyny. Merezhkovsky's reflection, yet again, is inclining towards the antagonism of "noumenon vs phenomenon": he sees the Biblical incarnation of homosexual "love" in sacred but also secular history (Sodom) as a symbol of the distortion of the Divine truth in a diabolical mirror. Merezhkovsky states: "Europe is Sodom" (Merezhkovsky 2007, p. 36), because the homosexual principle prevails there. According to Merezhkovsky, in the East of Europe, in the USSR, Communism with its gregarious pseudo-sobornost (pseudo-spiritual community) of "Hams who came there" imposes exclusive femininity, which is faceless and fruitless in its sole proprietorship. On the contrary, a similar impersonality and infertility are embodied in the West, in its self-sufficient masculinity, which is militarism. If the two of them collide, the result might be apocalyptic; the world would end up with the Second World War and the ultimate death of humankind. That is when Merezhkovsky's mythopoeic started exploring new semantic spheres and proceeded from the domain of "mysticism of sex" to pure historiosophy (where similar mythologeme works anyway) by using the same codes but slightly rearranging them.

\section{The Heavenly Kingdom as the Looking Glass Land}

In Jesus the Unknown, Merezhkovsky develops in depth the concept of the Heavenly Kingdom. He sees the main discrepancy between Christ and Christianity in its understanding. The decline of eschatology in Christianity, the disease of kázhenie (i.e., perception of God and devil as mythological creations) led Christianity to the loss of every trace of experiencing an inseparable union of God and the world, to a separation of mundane 
and heavenly, fleshly, and spiritual. For a further, more vivid, illustration of his thought, Merezhkovsky introduces the ethnic symbols of "Judean" (syncretic) and "Aryan" (taken in Plato's discourse) imaginings of the Heavenly Kingdom. "The Third Testament" will be executed in the sensual-spiritual Heavenly Realm where it will transform into the "Ecumenical Church of Godmanhood". The Law transcended by Love will be finalized by Freedom, and the "Unknown Eucharist of Jesus the Unknown" will be accomplished, and every man will really become part of the Divine Body in eternity. It is curious to note, however, that in the chapter "The Heavenly Kingdom," the most controversial in the whole text of Jesus the Unknown, Merezhkovsky comes to fairly Orthodox conclusions, similar to those made at the Council of Chalcedon, about the Heavenly Kingdom, which, pre-existing in eternity, is establishing itself in real history in real time.

The actual present and the historical time in general look like an "upside-down" quote of the future of the Third Testament. This present exists in the field of a paradox, as a mirror opposition to the Heavenly Kingdom:

... come out of this world, out of three dimensions and come into that other world, into the fourth dimension, where bottom becomes top and top bottom, when right becomes left and left right: where everything is vice versa. Only "getting upside down," "falling down," only "head first," to everyone else's horror, who pretends to stand steadily, who is "reasonable," you can enter, fly in, fall in, from this world into that one, from the kingdom of men to the Heavenly Kingdom, from earthly sorrow to heavenly bliss (Merezhkovsky 1996, p. 262).

The pathos of the present is exactly here. On its providential tops (Merezhkovsky's historicism does not know anything else) the present is experiencing the tragic conflict between the "pre-knowledge" of truth, which is rising within, and the impending doom of the mundane "here and now".

History for Merezhkovsky, as for the other Russian Modernists, is drama and the theatre of symbols in which a man is either a player or a marionette. It does not matter for him if his concept does not get along with the "historic accuracy" as well as with the logic of mythological concepts, because everything "historical" makes sense only in the correlation with "mysterial". Mysterial and historical were merged altogether only in the ministration of Jesus Christ. In all other cases they are tragically divided. Talking about the unbreakable connections between history and mystery in one of the canonical Gospels, Merezhkovsky has noted:

These two metals are merged by Matthew in fire that is the hottest, into the strongest amalgam, therefore, they are not two anymore but one; that one that happened once in time, in history, exists and will continue in eternity, in mystery; the first day of the Lord is the Heavenly Kingdom that has already come (ibid., p. 259).

An analysis of the existence of the New Testament theme in Merezhkovsky's discourse becomes an additional basis for the conclusions that by the 1920s became the compilation in regard to practically all the texts of the Russian fin de siècle culture, such as the philosophy of the All-Unity, "Russian Cosmism," actual Symbolism in its different hypostases, Rozanov's "physiology," "Christianised" Nietzscheism, transformed Sophiology, and sexual theories by Weininger as well as many other systems of views, which provided lots of material forthe doctrinal mosaics of Merezhkovsky.

Merezhkovsky becomes almost the most consistent spokesman of couleur locale of the Symbolist historicism, which was described by one of the modern researchers as follows:

The aestheticization of life, from one side, and the transformation of aesthetics into the daily program, from the other, has been shown as the most vivid in the historical worldview. The history of the world as a whole is an aesthetical fact, an artefact, and the "text." The correlation between one event and another is perceived as quotation. Symbolic "quoting" of one event via another is the action of the transformation of a denotative event to an event of denotation (Isupov 1992, p. 89).

Originating from Romanticism, the Symbolist mythologeme of the author-Demiurge had been consistently shifted by Merezhkovsky into the field of religion. Yet still, the 
deep-rooted role of the writer first and foremost was established around the metaphysical distillation of the global Symbolist aestheticism in order to give it global recognition. Generally speaking, Georgy Adamovich had every reason to note that:

Without Merezhkovsky, Russian Modernism could become truly Decadent, and it was he who from the very beginning made it strict, serious, and clear. $<\ldots>$ There was the return to the greatest themes of Russian literature, to the large-scale themes overall (Adamovich 1996, p. 27).

\section{Poetics and Politics on the Metaphysical Background: The Symbolist-Chiliast between Dante and Mussolini}

By 1930 Merezhkovsky was almost the only intellectually significant Russian figure in exile remaining following the tradition of the Modernist religious mythology and seeking to integrate the neo-Christian ideology.

The question about the results of an interaction between Art and the "God-seeing" fields during the late period of Merezhkovsky's life in Paris gets even more interesting considering his efforts to integrate the neo-Christian ideology, which grew up in the soil of the Russian Silver Age-in its sterile and preserved version-into the drastically different cultural context of Europe between the two world wars. We will focus only on a few significant aspects of this broad theme, connected to Merezhkovsky's book, Dante (1938), but beforehand let us make a general remark.

In Merezhkovsky's version, chiliastic mythology shows typical ambivalence. On the one hand, it inclines to a certain "historical Monophysitism," to full rejection of the providential essence of historical statehood. On the other hand, however, the ideological constructions of Merezhkovsky have always had that obvious Positivist nuance, the aspiration to make metaphysical categories more ordinary and, especially, the category of the "future age," the aeon of the Millennial Kingdom. In the author's mind, the "rose" of religious and Symbolist metaphysics acquired a scent only if propagated by the "wild branch" of the political volatility of the era.

Along with that, chiliastic mythology, as well as the other fin de siècle Modernist constructions, reveals a tendency to expansive deforming impact first on the actual aesthetical sphere, and then, as a reflectionon life, per se, in nearly all its manifestations.

As a way of highlighting the seriousness of the wild branch to Merezhkovsky is the story while he worked on his Dante, is his apparent admiration of the character and work of Benito Mussolini, then Italian Prime Minister. Mussolini had invited the Merezhkovskys to Italy to make certain investigations funded through a scholarship by the Fascist government ${ }^{10}$. In May 1936, during a time of intense work on the first part of the book, Merezhkovsky wrote a letter of acceptance and thanks to Mussolini. The letter is written in French and is of considerable historical interest and was first published in a monograph by T. Pachmuss (Pachmuss 1990, pp. 9-14). A few phrases and expressions from this letter were transferred afterwards into the "Introduction" to the Italian translation of Dante, which was released with the inscription, "To Benito Mussolini. $<$ This Book> about Dante the Prophet to the executor of the prophecy" [A Benito Mussolini. Realizzatoredellaprofeciaquestosu Dante profero] (Merezkovski 1938, p. 3).

In this very diplomatic epistle, accepting the historical determination and justification of the concordat between the Fascist regime and the Vatican, Merezhkovsky unfolds the dialectics of his own views on the relationship between the power of Caesar and that of the high priest. Criticising Dante's dual model of the necessity of an unmerged cooperation of the Emperor and the Pontiff, he makes the following conclusion:

$\langle\ldots\rangle$ the final resolution of the religious problem in the relationship between the Church and the State, the Cross and the Eagle, does not consist in forming an empirical or abstract alliance, not in a Concordat and, especially, not in their remoteness from each other, but in the perfect union, corresponding with the main Christian dogma, which is the union of two eternal powers, human and divine, earthly and heavenly in Christ's Persona, the Priest of priests and the King of kings. (Pachmuss 1990, p. 14) 
Reflecting upon the phenomenon of a poet in the meta-historical context, Merezhkovsky foresees the ontological and providential "affinity" between Mussolini and the spirit of the great Florentine poet. The concordat between Rome and the Vatican, Mussolini's intransigence against the "Bolsheviks' barbarism" and the Duce's "affection" during the first audience with the writer that facilitated and resulted in the scholarship funding.

From the outset the letter is remarkable:

I am very well aware that I need to thank you for the pleasure I have been granted through the invitation to come to Italy not with words but with deeds, with my work, a book about Dante. I came in order to collect documents about him, but the best ever evidence of all about Dante is you. To understand Dante, one should live by him, but it is possible only with you, in you ...

"I have been living with Dante all my life," you told me once. In your actions, you have implemented this life with Dante...

There is pre-established harmony between him and yourself. Your souls are initially and indefinitely related; they are destined to each other for very eternity. Mussolini in meditation is Dante. Dante in action is Mussolini (Pachmuss 1990, p. 9).

Further on, these flatteries change into three insistent demands he makes on the dictator. First, in the political sphere, to commence war against Russian Bolshevism ("satanic Communism"). In the social sphere, to implement in reality the all-human hopes and aspirations for universal peace via Dante's messianic ideas, avoiding the last and the most disastrous war. Finally, in the religious sphere, to attain the union of the historical churches under one Ecumenical Church, and execute the prophecy of his great predecessor and prepare the grounds for the coming of the new "Revelation of the Holy Spirit."

The author tenaciously imposes on the addressee the messianic and apocalyptic spirit of the Russian "God-seeking" Symbolists, doing so from the chiliastic perspective, which the Europe of the 1930s was not familiar with. It was Mussolini, who according to Merezhkovsky, should become the providential power, the one and only able to protect the world from the tragic "fate of Atlantis" in the pessimistic, Spenglerian, sense. It is worth noting that the most important epithets that Merezhkovsky uses towards Mussolini are these French lexemes Pacificateur and Consolateur, which literally mean "peacemaker" and (sic!) "comforter." Hence, for a person brought up in the Russian Orthodox Christian tradition, there is a transparent allusion to the verse 14:26 of the Gospel of John, where the Savior gives to His disciples the promise of the coming of the Holy Spirit, which is named by the polysemantic Greek word, parakletos ("the intercessor, who is called for help and is standing nearby ...") and is translated in Old Slavonic (but not necessarily in other languages) exactly as "Comforter." It is obvious that Mussolini could not understand this wordplay with a sacred intertext and with a mild allusion to the Slavic/Russian subtext. However, the author of the prophetic epistle to the dictator remained permanently monological and very often assumed monolingualism of any of his addressees for no good reason. Apparently, as a Symbolist, in this fragment Merezhkovsky gave a reference to the Orthodox prayer, the invocation of the Third Hypostasis of the Trinity "O Heavenly King": addressed to Mussolini, it should be regarded in the perspective of the upcoming era of the "Third Testament," "The Realm of the Heavenly Spirit," where "Duce" is the predecessor, according to Symbolist logic.

In Russian literature there is a tradition of the cultural communication between those in power and the artist. A writer addresses words of flattery and exaltation to the head of State in order to gently impose not only random political advice, but to some extent his own intellectual patronage. In one way or another, this narrative was used by Nikolay Karamzin and Tsar Alexander I, by Alexander Pushkin and Tsar Nicholas I, and even by Boris Pasternak and Stalin. Merezhkovsky's letter can be seen as a similar attempt to apply this role to him.

Yet at the same time Merezhkovsky goes beyond the limits of the strictly Russian cultural situation. His narrative looks fairly similar, but also holds another, symbolic, component, which refers to the Italian mediaeval and Renaissance tradition. The artist 
is seeking the duke or tyrant's patronage by inflating his intellectual ago. This model in Merezhkovsky's case obtains a certain Dante-esque meaning. The letter to Mussolini in the core of its "poetics" directly corresponds to two famous epistles written by Dante in 1311, The Letter to the Princes and Peoples of Italy (Dante wrote it on the occasion of Henry VII's campaign in Italy in order to be crowned as the Holy Roman Emperor in the Church of San Marco in Rome) and The Epistle to Henry VII the Emperor.

Merezhkovsky quotes the first letter in his book about Dante (Merezkovski 1938, p. 112); as for the second one, whilst not naming it literally, he undoubtedly implies it, simply because its subject is described in detail in the chronologically relevant part of the biography (ibid., pp. 113-20). Both epistles are examples of the scholastic epistolary rhetoric of the 13th-14th centuries, whose main claim was to project real events onto examples from the Sacred History by using the typical quotes and reversed allusions from the divine texts.

The rhetoric of scholastic Mannerism in the Dante-esque style became very congenial to Merezhkovsky, taking into account the peculiarity of the cultural mise en scène he is trying to recreate-and quite sincerely-in his letter to Mussolini. As for the second epistle by Dante, the letter to Henry VII, its content can already be the direct analogue to Merezhkovsky's letter to "Duce." In this epistle, after comparing the Emperor to Biblical and ancient heroes, Dante addresses to him the concerns of an exile from treacherous Florence. He reminds Caesar of the providential meaning of the Empire in building the Divine Salvation and requests the Emperor to leave Milan for the sake of completing the peace process and to turn his spears to Florence, the nest of the sin of Judas, the place of malice and the resistance to the unity of the Caesar ecumene, instead.

Merezhkovsky as an exile recreates the same situation, trying on Mussolini the role of the "secular Messiah," the collector of lands, and calling him to the crusade against Russian Bolshevism as the main threat on the way to global union. That is how the writer extrapolates a historical narrative that already became a fact of literature into the current political reality. Functionally, the roles remain the same, only their conceptual substance somewhat changed: it has to correspond with the "ready-made" historiosophical concept about Dante who declared the prophecy about an execution of "The Mystery of the Three" in the future, craving for the All-Unity in the real life and hanging his hopes on the "Imperial" spirit and the "Imperial" actions. He, however, did not perceive the empire itself in the eschatological way, and in this case the poet's aspirations were lower towards the shining truth of the "Third Testament." Only Merezhkovsky managed to "decipher" all Dante's prophecies that were hidden from Dante himself, and to relate a proclamation about the religious and historiosophical mission of "Messiah the Emperor" to the "Titan figure" of Mussolini. Hence, the model of the cultural communication "Merezhkovsky/Mussolini" is deliberately oriented on the metaphor of the "Magi who came from the East" (i.e., Russia) to worship the "born Messiah" (Mussolini) and to witness the execution of the Old Testament's soteriological prophecies.

That is how the purely personal preferences of Merezhkovsky the thinker and writer in the social and political European discourse of the 1930s yet again revealed the tendency, which was quite common in chiliastic Symbolism overall, of the replacement of "life" by literature and its dubious conversion that led not only to unpleasant historical misunderstandings, but also to real tragedies.

The entire religious symbolization of the reality by Merezhkovsky ended up adopting the sacred status in nearly all of his personal activities, including social and political life. The actions of the "military commanders on the ground" can only be interpreted with the help of the baroque and symbolical "sacred code," which could be imposed on these commanders, who did not always have a particular desire to accept it. That is how most of those peculiar conflicts of cultural communication between Merezhkovsky and his political addressees started.

Of course, the "romance" between Merezhkovsky and Mussolini, where the Danteesque subtext was prevailing, thanks to the Russian Symbolist, was doomed from the very 
beginning due to the very essence of the cultural and historical mythology of Merezhkovsky. It became the core subject in reflections on the matter by Yuri Terapiano:

Mussolini replied to Merezhkovsky's call to start a campaign against Bolshevism, "the utmost devilish evil of the world": "Italy, with its limited military forces, cannot start a fight with the mighty Soviet Army." And Merezhkovskythen said, "he was right in the sense of the bad infinity, but in the metaphysical sense he turned out as a misbeliever." That is what Merezhkovsky was telling us on one of the "Sundays" at his house, when he came back from his second, unsuccessful, trip to Italy. "At first, I thought that Mussolini was the incarnation of the spirit of the earth and a providential personality, and guess what? He turned out to be the usual materialistic politician—and a vulgar one!" Merezhkovsky shouted. Before that, similarly vulgar were other politicians, such as Piłsudski, and before him Hitler. They all thought about "history," i.e., the "bad infinity," and were unable to see "the end of history." And Merezhkovsky, who lived by metaphysics, could not fathom that other people were absolutely unfamiliar with that, and tried to see that metaphysical alikeness in every politician (Terapiano 1953, p. 31).

In the 1930s, Merezhkovsky definitely saw his mission not in literary activities but in prophetical service in the social and political arena. The Terapiano has noted that Merezhkovsky wanted to be judged not by the literary laws, but by his religious and philosophical experiences, which directly originated from the chiliastic concept of the Third Testament; in his last years, he bitterly complained about the critics who did not understand him, trying to use strict literary criteria towards his work:

He felt like he was the forerunner and also the main ideologist of the coming Kingdom of the Spirit. Dictators, like, for example, Jeanne d'Arc, must execute their mission, and he, Merezhkovsky, must give away the guidelines. Was it naïve? For sure, it was naïve in the historical sense, but in the metaphysical level, where Merezhkovsky lived, "naïve" became wise and "absurdist" turned into the most important. That is what Merezhkovskybelieved (ibid.).

Funding: This research received no external funding.

Institutional Review Board Statement: Not applicable.

Informed Consent Statement: Informed consent was obtained from all subjects involved in the study.

Data Availability Statement: Not applicable.

Conflicts of Interest: The author declares no conflict of interest.

\section{Notes}

Sallust. Concerning the Gods and the Universe.

First of all, Osiris, Dionysian and like mysteries that suggest a sacrificial dismembering.

For a detailed overview of the Egyptian theme in Russian literature and for an anthology of selected texts see (Panova 2006).

Merezhkovsky had already pointed out at the logical inevitability of this alternative in Rozanov's framework in the 1900s: (Merezhkovsky 1908, p. 95).

5 About the cultural role of the androgyne mythologeme in neo-Romanticism and Symbolism, see (Crouzet 1984). For a brief consideration of the same question (also an abstract) on the material of motivic reminiscences and allusions, see (Kozlov 1994). Isis and Osiris, Ishtar and Tammuz, the image of one entity with two faces, Hera and Zeus, on ancient coins.

7 Traditional Christian exegetics interprets this grammatical form as a secret notion of the Three Hypostases of One God (the verb in this grammatical construction is used in the singular). It is worth noting that Merezhkovsky, inspired by theology of "The Three in One," being very well aware of the literature on the subject and certainly knowing about this interpretation, did not find it necessary to make even a quick reference to it.

8 One can find the connections to it in the works of Clement of Alexandria, whom Merezhkovsky highly appreciated. A reference to his article "The Coming of Ham" from 1906.

10 For more details about the history of the book and the "Dante-esque" context of the relationship between Merezhkovsky and Mussolini see (Caprioglio and Spengel 1989; Dodero Costa 1999; Polonsky 2006, 2011, pp. 251-65). 


\section{References}

Adamovich, Georgy. 1996. Odinochestvo i svoboda. Moscow: Respublika, ISBN 5-250-02570-6.

Bedford, Harold C. 1975. The Seeker: D.S. Merezhkovsky. Kansas: University of Kansas Press, ISBN 9780700601318.

Bely, Andrey. 1997. Andrey Bely o Bloke: Vospominaniya. Statyi. Dnevniki. Rechi. Moscow: Avtograf, ISBN 5-89612-001-X.

Caprioglio, Nadia, and G. Spengel. 1989. Dmitrij Merezkovskij e Dante Alighieri. In Dantismo russo e cornice europea: Atti dei convegni di Alghero-Gressoney (1987). Firenze: Olschky, pp. 341-51. ISSN 0066-6807.

Chaubet, François. 2000. Paul Desjardins et les Décades de Pontigny. Paris: Presses Universitaires du Septentrion, ISBN 2-85939-606-3.

Crouzet, Michel. 1984. Monstres et merveilles: Poétique de l'Androgyne, à propos de Fragoletta. Romantisme 14: 25-42. [CrossRef]

Dodero Costa, Maria-Luisa. 1999. O knige Merezhkovskogo “Dante”. In D.S. Merezhkovsky. Mysl' i slovo. Moscow: Nasledie, pp. 82-88. ISBN 5-201-13314-2.

Fridlender, Georgy M. 1995. D. S. Merezhkovsky I Genrik Ibsen (U istokov religiozno-filosofskikh idey Merezhkovskogo). In Fridlender G. M. Pushkin. Dostoyevsky. "Serebriany vek". Saint-Petersburg: Nauka, pp. 411-34.

Gaidenko, Piama. 2000. D. S. Merezhkovsky: Apokalipsis "vsesokrushayuschey religioznoy revolutsii". In Voprosy literatury. ${ }^{\circ} 5$. Moscow: FSRL "Literaturnaya kritika", pp. 98-126. ISSN 0042-8795.

Gaidenko, Piama. 2001. Vladimir Solovyov I Filosofiya Serebrianogo veka. Moscow: Progress-Traditsia, ISBN 5-89826-076-5.

Gippius, Zinaida N. 1999. Dnevniki: V 2 kn. Kn.1. Moscow: Intelvak, ISBN 5-93264-006-5.

Goncharova, Elena I. 2009. "Revolutsionnoe khristovstvo": Pis'ma Merezhkovskogo k Borisu Savinkovu. Vstup. st., sost., podgot. Tekstov i comment. E.I. Goncharovoy. Saint-Petersburg: Pushkinsky Dom, ISBN 978-5-91476-009-7.

Isupov, Konstantin G. 1992. Russkaya estetika istorii. Saint-Petersburg: Izd-voVyschihk guman. kursov.

Kozlov, Sergey L. 1994. Lyubov k androginu. Blok-Akhmatova-Gumilyov. In Tynianovsky sbornik. Piatye tynianovskie chteniya. Riga: Zinatne, pp. 155-72. ISBN 5-7966-1033-3.

Kozyrev, Alexey. 1996. Vladimir Solovyov i Anna Schmidt v chaianii “Tret'yego Zaveta”. In Rossiya i gnosis: materialy konferentsii. Moscow: Rudomino, pp. 23-42.

Literaturnoy enasledstvo. 1980. Literaturnoy enasledstvo, t. 92: Aleksandr Blok: Novye materially i issledovaniya, kn. 1. Moscow: Nauka.

Löwith, Karl. 1949. Meaning in History, The Theological Implications of the Philosophy of History. Chicago: University of Chicago Press.

Matich, Olga. 1999. O. Khristianstvo Tret'yego Zaveta i traditsia russkogo utopizma. In D.S. Merezhkovsky. Mysl' islovo. Moscow: Nasledie, pp. 106-18. ISBN 5-201-13314-2.

Matich, Olga. 2008. Eroticheskaya utopia: novoe religioznoye soznaniei fin de siècle v Rossii. Moscow: NLO, ISBN 978-5-86793-642-6.

Merezhkovsky, Dmitry S. 1907. La Question religieuse. In Mercure de France. ${ }^{\circ} 1$. Paris: Mercure de France, V, pp. $40-71$.

Merezhkovsky, Dmitry S. 1908. Ne mir, no mech: K budushchey kritike khristianstva. Saint-Petersburg: M.V. Pirozhkov.

Merezhkovsky, Dmitry S. 1933. Blazhenstva. In Chisla. Paris: Cahiers de l'étoile, pp. 195-209.

Merezhkovsky, Dmitry S. 1996. Iisus Neizvestny. Moscow: Respublika, ISBN 5-250-02601-.

Merezhkovsky, Dmitry S. 1999. Taina Tryokh. Moscow: Respublika, ISBN 5-250-02718-0.

Merezhkovsky, Dmitry S. 2007. Taina Zapada: Atlantida-Europa. Moscow: Exmo, ISBN 978-5-699-21997-1.

Merezkovski, Dmitri. 1938. Dante. Trad. di Rinaldo Küifferle. Bologna: Zanichelli.

Mozgovaya, Ya E. 1996. V. S. Solovyov i D. S. Merezhkovsky. In Otechestvennaya filosofiya: Opyt, Problemy, Orientiry issledovaniya, vyp.19. Moscow: AON, pp. 112-25.

Pachmuss, Temira. 1990. D.S. Merezhkovzky in Exile. The Master of the Genre of Biographie Romancée. New York: P. Lang, ISBN 0-8204-1254-6.

Panova, Lada. G. 2006. Russky Egipet. Aleksandriyskaya poetika Mikhaila Kuzmina: V 2 kn. Moscow: Vodoley Publishers, ISBN 5-902312-80-9.

Pavlova, Margarita. 1999. Mucheniki velikogo religioznogo protsessa. In Tsar i revolutsiya. Pod. red. M. A. Kolerova. Edited by Dmitry Merezhkovsky, Zinnaida Gippius and Dmitry Filosofov. Moscow: OGI, pp. 7-54. ISBN 5-900241-42-4.

Polonsky, Vadim V. 2006. Mezhdu metafizikoy, istoriey i politikoy: religioznaya mifologiya v pozdnem tvorchestve D. S. Merezhkovskogo. In Voprosy literatury. Moscow: FSRL “Literaturnaya kritika”, pp. 186-99. ISSN 0042-8795.

Polonsky, Vadim V. 2011. Mezhdu traditsiey i modernizmom. Russkaya literature rubezha XIX-XX vekov: istoriya, poetika, kontekst. Moscow: IMLI RAN, ISBN 978-5-9208-0389-4.

Rosenthal, Bernice G. 1975. Merezhkovsky and the Silver Age: The Development of a Revolutionary Mentality. The Hague: Springer, ISBN 978-9401183536.

Terapiano, Yury. 1953. Vstrechi. New York: Izd-vo im. Chekhova. 